\title{
VAIKU巳, GIMUSIŲ SU LŪPOS, ALVEOLINĖS ATAUGOS IR GOMURIO NESUAUGIMAIS, NUO BURNOS SVEIKATOS PRIKLAUSANTI GYVENIMO KOKYBE்
}

\author{
Linas Zaleckas ${ }^{1}$, Laura Linkevičiene் $\dot{2}^{2}$, Greta Aidukaite் ${ }^{2}$, Greta Bagušauskaite் ${ }^{2}$ \\ ${ }^{I}$ Vilniaus universiteto Medicinos fakulteto Odontologijos institutas, \\ Vilniaus universiteto ligoninès Žalgirio klinika, \\ ${ }^{2}$ Vilniaus universiteto Medicinos fakulteto Odontologijos institutas
}

Raktažodžiai: lūpos nesuaugimas, gomurio nesuaugimas, gyvenimo kokybè, burnos sveikata, "Vaikų burnos sveikatos poveikio skalë“.

\begin{abstract}
Santrauka
Lietuvoje su lūpos, alveolinès ataugos ir/ar gomurio nesuaugimais gimsta 1 iš 700-800 vaikų. Tai yra kompleksine patologija, apimanti anatominius, fiziologinius, psichologinius procesus, kurie keičia gyvenimo kokybę.

Darbo tikslas - įvertinti vaikų, gimusių su lūpos, alveolinès ataugos ir/ar gomurio nesuaugimu, nuo burnos sveikatos priklausančią gyvenimo kokybę bei nustatyti, ar skiriasi gyvenimo kokybès rodikliai atsižvelgiant ị nesuaugimo tipą, pacientų amžių, lytị, palyginti tėvų/globejų atsakymus vertinant vaikų nuo burnos sveikatos priklausančią gyvenimo kokybę.

Medžiaga ir metodai. Tirti 45 Vilniaus universiteto ligoninès Žalgirio klinikos pacientai, gimę su lūpos ir/ar gomurio nesuaugimu, taip pat vienas iš jų tèvų/ globėjų bei 45 kontrolinès grupès asmenys. Tyrimas atliktas nagrinėjant tiriamujų užpildytą, standartizuotą vaiko burnos sveikatos nulemtos gyvenimo kokybès klausimyną lietuvių kalba (angl. Child Oral Health Impact Profile - COHIP). Dalyvavusių vaikų amžius 8-15 metur.

Rezultatai. Vaikų, gimusių su nesuaugimu, gyvenimo kokybė yra prastesnè nei sveikų vaikų $(\mathrm{p}<0,001)$. Vidutinis jų surinktas COHIP balas 108,80 $\pm 13,26$, o kontrolinès grupès $125,78 \pm 11,43$. Labiausiai tai atsispindi vertinant funkcinę gyvenimo gerovę, socialinę-emocinę gyvenimo gerovę, mokyklos aplinką, bendrą sveikatą $(p<0,001)$ bei bendrą burnos sveikatą $(p=0,05)$. Nerasta reikšmingo skirtumo lyginant atsakymus skirtingose amžiaus grupèse, tarp skirtingų
\end{abstract}

lyčių bei tarp vaikų, turinčių skirtingus nesuaugimo tipus. Nustatyta, kad tevai/globejai statistiškai blogiau vertina vaikų nuo burnos sveikatos priklausančią gyvenimo kokybę, ypač funkcinę, socialinę-emocinę gyvenimo gerovę, mokyklos aplinką bei bendrą burnos sveikatą nei patys vaikai.

Išvados. Pacientų, gimusių su lūpos, alveolinès ataugos ir/ar gomurio nesuaugimu nuo burnos sveikatos priklausanti gyvenimo kokybė yra prastesnè nei sveikų vaikų. Tèvai savo vaikų, gimusių su nesuaugimu, gyvenimo kokybę vertina blogiau, nei patys vaikai. Amžiaus grupe, lytis bei nesuaugimo tipas neturi itakos gyvenimo kokybei.

\section{İvadas}

Lūpos ir/ar gomurio nesuaugimas yra labiausiai paplitusi igimta vystymosi anomalija galvos srityje. Ji sudaro vidutiniškai 1,5 atvejo iš 1000 naujagimių, dažniau Azijos, Europos populiacijose [1]. Lietuvoje su šiais nesuaugimais gimsta 1 iš 700-800 vaikų. Tai yra kompleksinè patologija, apimanti daugeli paciento anatominių, fiziologinių, psichologinių procesų. Norint pasiekti maksimalų gydymo efektą, reikia gydytojų specialistų komandos - veido ir žandikaulių chirurgo, ortodonto, otorinolaringologo, pediatro, logopedo, slaugytojo, gydytojo genetiko, psichologo, socialinio darbuotojo ir kitų [2]. Nepaisant pažangių gydymo metodų, lūpos ir/ar gomurio nesuaugimą turintys pacientai susiduria su didelèmis sveikatos problemomis, kurios keičia gyvenimo kokybę. Pradinès chirurginès intervencijos atliekamos jau pirmaisiais gyvenimo ménesiais ir metais, tačiau pagrindiniai funkciniai (dantų vystymasis, kalba) ir estetiniai (veido bruožai) aspektai galutinai koreguojami tik mokyklinio amžiaus vaikams bei jaunuoliams. Be to, pacientai kenčia ne tik nuo morfologinių sutrikimų, bet ir nuo socialinių problemų. Visa tai gali sukelti pirmuosius psichologinius sutrikimus: susier- 
zinimą, savęs nuvertinimą ar net depresijos požymius [3]. Taip pat svarbu paminèti ir galimus žymius kalbos sutrikimus, kurie išlieka net ir po operacinių intervencijų [4]. Visus šiuos aspektus apjungia nuo burnos sveikatos priklausančios gyvenimo kokybės sąvoka. Ji sujungia individo burnos sveikatos, funkcinès, emocinès gerovès, lūkesčių, pasitenkinimo gydymu, požiūrio ị save bei kitus svarbius klausimus. Nuo burnos sveikatos priklausanti gyvenimo kokybė yra Pasaulio sveikatos organizacijos pripažinta priemonè gydymo efektyvumui ir reikalingumui ivvertinti [5]. Panašių tyrimų šia tema nebuvo atlikta ne tik Lietuvoje, bet ir gretimose šalyse - Latvijoje, Estijoje, Lenkijoje.

Tyrimo tikslas - įvertinti vaikų, gimusių su lūpos, alveolinès ataugos ir/ar gomurio nesuaugimu, nuo burnos sveikatos priklausančią gyvenimo kokybę bei nustatyti, ar skiriasi gyvenimo kokybès rodikliai atsižvelgiant ị nesuaugimo tipą, pacientų amžių, lytį. Taip pat siekta palyginti tèvų/globẻjų atsakymus apie jų vaiką su atskirai vaikų išsakyta nuomone.

\section{Tyrimo objektas ir metodika}

Tyrimo grupę sudare 45 asmenys, gimę su lūpos, alveolinès ataugos ir/ar gomurio nesuaugimu bei gydyti Vilniaus universiteto ligoninès Žalgirio klinikoje arba buvo atvykę konsultacijai nuo 20170101 iki 20170901 bei vienas iš jų tėvų/globejjų. Tiriamųjų amžius $-8-15 \mathrm{~m}$. I kontrolinę 45 tiriamujų grupę itraukti 8-15 metu amžiaus asmenys, atvykę i Vilniaus universiteto ligoninės Žalgirio kliniką profilaktinei dantų patikrai prieš mokyklą, neturintys veido nesuaugimų ir kitų žinomų vystymosi ydų. Duomenys rinkti anonimiškai, prieš tai gavus informuotą, raštišką vieno iš paciento tèvų/globejjo sutikimą dalyvauti tyrime. Buvo naudota standartizuota "Vaiko burnos sveikatos poveikio skale“" (angl. Child Oral Health Impact Profile, COHIP), kuri pasižymi puikiu patikimumu, pakartojamumu, pagrịstumu ir yra plačiai naudojama ịvairiuose tyrimuose kitomis kalbomis [6, 7]. Tai - 38 klausimų anketa, kurioje pateikiami klausimai apie burnos sveikatą, funkcinę savijautą, socialinęemocinę savijautą, mokyklos aplinką, savęs suvokimą, gydymo lūkesčius ir bendrą vaiko sveikatos būklę. Kiekvienas atsakymas vertintas naudojant Likerto (Likert) skalę balais nuo 0 iki
4. Kuo didesnė anketos balų suma, tuo geresnè nuo burnos sveikatos priklausanti gyvenimo kokybė. Anketa buvo išversta ị lietuvių kalbą, atliktas atgalinis vertimas, palyginta, paruošta galutinè lietuviška versija, kuri buvo patikrinta atliekant kontrolinị tyrimą tarp dešimties panašaus amžiaus tyrime nedalyvaujančių vaikų bei jų tèvų/globejjų. Kelios

1 lentelè. Kontrolinės grupès ir vaikų, gimusių su nesuaugimu, surinktų balų palyginimas.

SD-standartine deviacija, $\bar{x}$ - vidurkis

\begin{tabular}{|c|c|c|c|}
\hline COHIP klausimynas & $\begin{array}{l}\text { Vaikai su nesuau- } \\
\text { gimu }(n=45) \\
\text { Kontrolinė grupè } \\
(n=45)\end{array}$ & $\overline{\mathbf{x}} \pm$ SD & $\begin{array}{c}\text { Skirtu- } \\
\text { mas tarp } \\
\text { tiriamųjų } \\
\text { grupių }\end{array}$ \\
\hline $\begin{array}{l}\text { Bendras burnos sveikatos poveikio } \\
\text { skalès balas }\end{array}$ & $\begin{array}{c}\text { Vaikai su nesuaugimu } \\
\text { Kontrolinė grupe }\end{array}$ & $\begin{array}{l}108,80 \pm 13,26 \\
125,78 \pm 11,43\end{array}$ & $16,98 * *$ \\
\hline Su burnos sveikata susijusi gerovè & $\begin{array}{l}\text { Vaikai su nesuaugimu } \\
\text { Kontrolinė grupé }\end{array}$ & $\begin{array}{l}26,24 \pm 5,55 \\
28,78 \pm 4,91\end{array}$ & 2,54 \\
\hline Funkcinė gyvenimo gerovė & $\begin{array}{l}\text { Vaikai su nesuaugimu } \\
\text { Kontrolinė grupé }\end{array}$ & $\begin{array}{l}18,20 \pm 3,52 \\
22,44 \pm 2,07\end{array}$ & $4,24 * *$ \\
\hline $\begin{array}{l}\text { Socialinè-emocinè gyvenimo ge- } \\
\text { rové }\end{array}$ & $\begin{array}{c}\text { Vaikai su nesuaugimu } \\
\text { Kontrolinė grupe }\end{array}$ & $\begin{array}{l}26,13 \pm 4,71 \\
29,29 \pm 2,78\end{array}$ & $3,16^{* *}$ \\
\hline Mokyklos aplinka & $\begin{array}{l}\text { Vaikai su nesuaugimu } \\
\text { Kontrolinė grupé }\end{array}$ & $\begin{array}{l}14.62 \pm 1,64 \\
15,56 \pm 0,89\end{array}$ & $0,94 *$ \\
\hline Savęs suvokimas & $\begin{array}{c}\text { Vaikai su nesuaugimu } \\
\text { Kontrolinė grupe }\end{array}$ & $\begin{array}{l}18,11 \pm 3,42 \\
18,38 \pm 2,65\end{array}$ & 0,27 \\
\hline Gydymo lūkesčiai & $\begin{array}{l}\text { Vaikai su nesuaugimu } \\
\text { Kontrolinė grupé }\end{array}$ & $\begin{array}{l}6,18 \pm 1,42 \\
6,29 \pm 1,20\end{array}$ & 0,11 \\
\hline Bendra sveikatos būklè & $\begin{array}{c}\text { Vaikai su nesuaugimu } \\
\text { Kontrolinė grupé }\end{array}$ & $\begin{array}{l}2,87 \pm 0,77 \\
3,33 \pm 0,64\end{array}$ & $0,46^{* *}$ \\
\hline Bendra burnos sveikatos būklè & $\begin{array}{l}\text { Vaikai su nesuaugimu } \\
\text { Kontrolinė grupé }\end{array}$ & $\begin{array}{l}2,58 \pm 0,78 \\
3,00 \pm 0,80\end{array}$ & $0,42 * *$ \\
\hline
\end{tabular}

2 lentelè. Vaikų, gimusių su nesuaugimu, skirtingose amžiaus grupėse surinktų balų palyginimas.

$S D$-standartine deviacija, $\bar{x}$-vidurkis

\begin{tabular}{|c|c|c|c|}
\hline COHIP klausimynas & $\begin{array}{c}\text { Amžius 8-11 metụ } \\
(n=23) \\
\text { Amžius 12-15 metų } \\
(n=22)\end{array}$ & $\overline{\mathbf{x}} \pm$ SD & $\begin{array}{c}\text { Skirtu- } \\
\text { mas tarp } \\
\text { tiriamųju } \\
\text { grupių }\end{array}$ \\
\hline $\begin{array}{l}\text { Bendras burnos sveikatos } \\
\text { poveikio skalès balas }\end{array}$ & $\begin{array}{l}\text { Amžius 8-11metų } \\
\text { Amžius 12-15 metų }\end{array}$ & $\begin{array}{l}103,74 \pm 18,06 \\
104,45 \pm 15,12\end{array}$ & 0,71 \\
\hline $\begin{array}{l}\text { Su burnos sveikata susijusi } \\
\text { gerové }\end{array}$ & $\begin{array}{l}\text { Amžius 8-11metų } \\
\text { Amžius 12-15 metų }\end{array}$ & $\begin{array}{l}26,91 \pm 4,98 \\
25,41 \pm 5,65\end{array}$ & 1,5 \\
\hline Funkcinė gyvenimo gerovė & $\begin{array}{l}\text { Amžius 8-11metų } \\
\text { Amžius 12-15 metų }\end{array}$ & $\begin{array}{l}16,70 \pm 4,30 \\
17,77 \pm 4,29\end{array}$ & 1,07 \\
\hline $\begin{array}{l}\text { Socialinè-emocinė gyvenimo } \\
\text { gerové }\end{array}$ & $\begin{array}{l}\text { Amžius 8-11metų } \\
\text { Amžius 12-15 metų }\end{array}$ & $\begin{array}{l}24,70 \pm 6,89 \\
25,36 \pm 5,38\end{array}$ & 0,66 \\
\hline Mokyklos aplinka & $\begin{array}{l}\text { Amžius 8-11metų } \\
\text { Amžius } 12-15 \text { metų }\end{array}$ & $\begin{array}{l}12,91 \pm 3,16 \\
13,77 \pm 2,47\end{array}$ & 0,86 \\
\hline Savęs suvokimas & $\begin{array}{l}\text { Amžius 8-11metų } \\
\text { Amžius 12-15 metų }\end{array}$ & $\begin{array}{l}16,70 \pm 4,07 \\
18,59 \pm 4,34\end{array}$ & 1,89 \\
\hline Gydymo lūkesčiai & $\begin{array}{l}\text { Amžius 8-11metų } \\
\text { Amžius } 12-15 \text { metų }\end{array}$ & $\begin{array}{l}5,61 \pm 1,53 \\
6,09 \pm 1,57\end{array}$ & 0,48 \\
\hline Bendra sveikatos būklè & $\begin{array}{l}\text { Amžius 8-11metų } \\
\text { Amžius 12-15 metų }\end{array}$ & $\begin{array}{l}2,57 \pm 0,95 \\
3,86 \pm 0,83\end{array}$ & 1,29 \\
\hline $\begin{array}{l}\text { Bendra burnos sveikatos } \\
\text { būklė }\end{array}$ & $\begin{array}{l}\text { Amžius 8-11metų } \\
\text { Amžius 12-15 metų }\end{array}$ & $\begin{array}{l}2,17 \pm 0,83 \\
2,41 \pm 0,91\end{array}$ & 0,24 \\
\hline
\end{tabular}


klausimų formuluotès tiriamiesiems nebuvo galutinai aiškios, atliktos atitinkamos korekcijos. Iš viso tyrime dalyvavo ir standartizuotą COHIP klausimyną užpilde 145 asmenys, bet penkios poros anketų i tyrimą nebuvo ịtrauktos. Viena pora - paciento, kuris sunkiai suprato lietuvių kalbą, todèl pildè padedamas globėjos, trys poros - dèl nepilnai užpildytų klausimynų, viena pora - dèl anketoje pažymèto igimto sindromo, turinčio įtakos psichomotoriniam vystymuisi. Tyrimo duomenys analizuoti vienodų imčiu grupèse: 45 vaikai, gimę su lūpos ir/ar gomurio nesuaugimu, 45 vaikų, gimusių su nesuaugimu, tèvai ar globejai bei 45 nesuaugimo neturintys vaikai (kontrolinè grupè).

Duomenų analizè buvo atliekama naudojant statistini paketą IBM SPSS Statistics 17.0 for Windows. Taikytas dviejų nepriklausomų imčiu T-kriterijus (Independent-Samples T Test). Statistiškai reikšmingi laikyti skirtumai, kai taikytų kriterijų reikšmė $\mathrm{p}<0,05$.

\section{Tyrimo rezultatai}

Tyrimo atsako dažnis buvo $100 \%$. Iš 45 vaikų su veido nesuaugimais, $37,8 \%(\mathrm{n}=17)$ buvo mergaitès ir $62,2 \%(\mathrm{n}=28)$ - berniukai. Pagal amžiaus grupes $51,1 \%(\mathrm{n}=23)$ vaikai buvo 8 -11 metu amžiaus ir 48,9\% (n=22) - 12-15 metų amžiaus. Iš 45 vaikų nesuaugimų grupeje $62,22 \%(\mathrm{n}=28)$ buvo gimę su vienpusiu lūpos, alveolinès ataugos ir gomurio nesuaugimu, 20,0\% $(\mathrm{n}=9)$ - su izoliuotu gomurio nesuaugimu, $11,11 \%(\mathrm{n}=5)$ su abipusiu lūpos, alveolinès ataugos ir gomurio nesuaugimu, $2,22 \%(\mathrm{n}=1)$ su lūpos ir alveolinès ataugos nesuaugimu, 2,22\% (n=1) su izoliuotu lūpos nesuaugimu, 2,22\% $(\mathrm{n}=1)$ su centriniu nosies, lūpos ir alveolinès ataugos nesuaugimu.

Lyginant tiriamuosius, turẻjusius nesuaugimą, su kontroline grupe buvo gautas statistiškai reikšmingas skirtumas vertinant bendrą vaikų burnos sveikatos poveikio skalès balą, taip pat funkcinę gyvenimo gerovę, socialinę-emocinę gyvenimo gerovę, mokyklos aplinką, bendrą sveikatą bei bendrą burnos sveikatą (1 lentelè). Nesuaugimą turinčių pacientų balai šiuose kriterijuose buvo statistiškai prastesni.

Analizuojant tiriamujų atsakymus skirtingose amžiaus grupèse, tiriamieji buvo padalinti į dvi grupes: 8-11 metų ir 12-15 metų (mediana - 11,7 metų; vidurkis 11,9 metų) ir taip gautos dvi pa- lyginamos grupès. Nustatyta, kad abi tiriamųjų grupès surinko panašu bendrą burnos sveikatos poveikio skalès balą, statistiškai reikšmingas balų skirtumas nerastas nei vienoje klausimų grupejje (2 lentelè).

3 lentelè. Vaikų, gimusių su nesuaugimu, ir jų tėvų/globejjų surinktų balų palyginimas.

SD-standartine deviacija, $\bar{x}$ - vidurkis

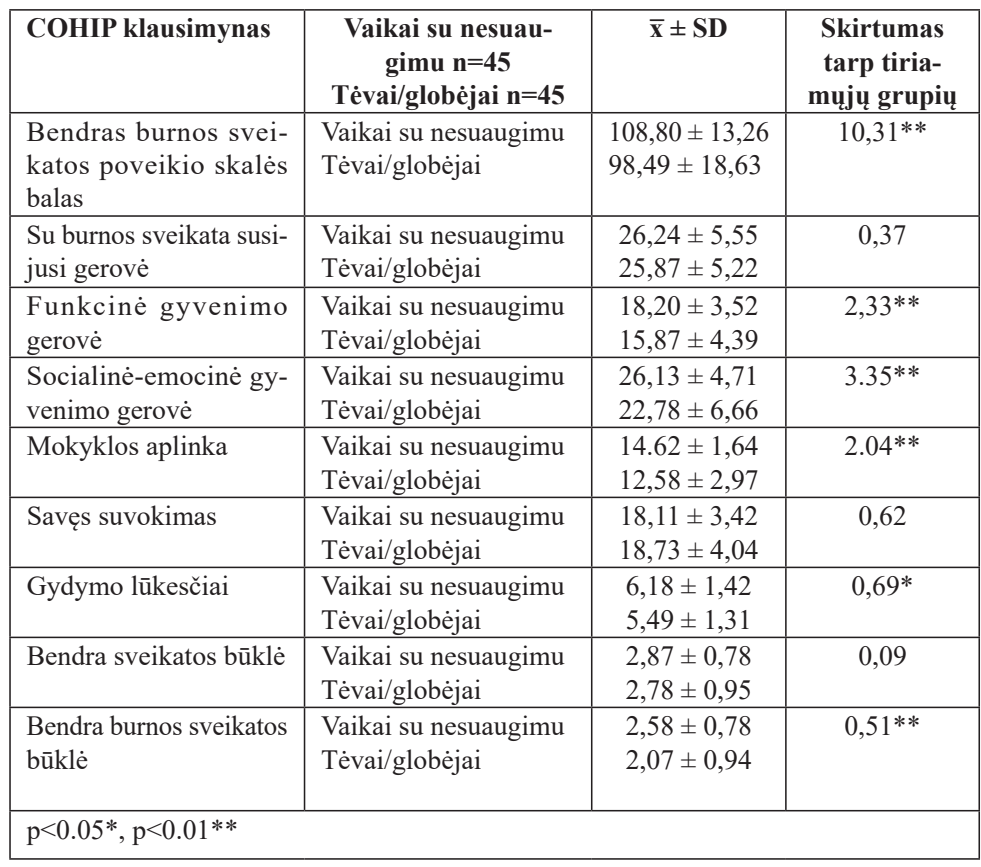

4 lentelė. Skirtingų lyčių vaikų, gimusių su nesuaugimu, surinktų balų palyginimas.

SD-standartine deviacija, $\bar{x}$ - vidurkis

\begin{tabular}{|c|c|c|c|}
\hline COHIP klausimynas & $\begin{array}{l}\text { Mergaitès } n=17 \\
\text { Berniukai } n=\mathbf{2 8}\end{array}$ & $\overline{\mathbf{x}} \pm \mathbf{S D}$ & $\begin{array}{c}\text { Skirtumas } \\
\text { tarp tiriamųjų } \\
\text { grupių }\end{array}$ \\
\hline $\begin{array}{l}\text { Bendras burnos sveikatos } \\
\text { poveikio skalès balas }\end{array}$ & $\begin{array}{l}\text { Mergaitės } \\
\text { Berniukai }\end{array}$ & $\begin{array}{l}109,94 \pm 12,45 \\
108,11 \pm 13,91\end{array}$ & 1,83 \\
\hline $\begin{array}{l}\text { Su burnos sveikata susi- } \\
\text { jusi gerové }\end{array}$ & $\begin{array}{l}\text { Mergaitès } \\
\text { Berniukai }\end{array}$ & $\begin{array}{l}25,76 \pm 5,18 \\
26,54 \pm 5,84\end{array}$ & 0,78 \\
\hline $\begin{array}{l}\text { Funkcinė gyvenimo ge- } \\
\text { rové }\end{array}$ & $\begin{array}{l}\text { Mergaitės } \\
\text { Berniukai }\end{array}$ & $\begin{array}{l}18,76 \pm 2,86 \\
17,86 \pm 3,88 \\
\end{array}$ & 0,9 \\
\hline $\begin{array}{l}\text { Socialinè-emocinè gyve- } \\
\text { nimo gerovè }\end{array}$ & $\begin{array}{l}\text { Mergaitès } \\
\text { Berniukai }\end{array}$ & $\begin{array}{l}26,12 \pm 4,23 \\
26,14 \pm 5,05\end{array}$ & 0,02 \\
\hline Mokyklos aplinka & $\begin{array}{l}\text { Mergaitės } \\
\text { Berniukai }\end{array}$ & $\begin{array}{l}14,94 \pm 1,14 \\
14,43 \pm 1,87\end{array}$ & 0,51 \\
\hline Savęs suvokimas & $\begin{array}{l}\text { Mergaitės } \\
\text { Berniukai }\end{array}$ & $\begin{array}{l}18,24 \pm 4,02 \\
18,04 \pm 3,07\end{array}$ & 0,2 \\
\hline Gydymo lūkesčiai & $\begin{array}{l}\text { Mergaitės } \\
\text { Berniukai }\end{array}$ & $\begin{array}{l}5,82 \pm 1,59 \\
6,39 \pm 1,27 \\
\end{array}$ & 0,57 \\
\hline Bendra sveikatos būklè & $\begin{array}{l}\text { Mergaitès } \\
\text { Berniukai }\end{array}$ & $\begin{array}{l}2,82 \pm 0,95 \\
2,89 \pm 0,69\end{array}$ & 0,07 \\
\hline $\begin{array}{l}\text { Bendra burnos sveikatos } \\
\text { būklè }\end{array}$ & $\begin{array}{l}\text { Mergaitės } \\
\text { Berniukai }\end{array}$ & $\begin{array}{l}2,59 \pm 0,80 \\
2,57 \pm 0,79\end{array}$ & 0,02 \\
\hline
\end{tabular}


Vertinant vaikų, gimusių su veido nesuaugimais, ir jų tėvų/ globejjų atsakymus nustatyta, kad tèvai/globejjai vaikų nuo burnos sveikatos priklausančią gyvenimo kokybę vertina prasčiau nei patys vaikai (3 lentelè). Statistiškai reikšmingas skirtumas gautas vertinant bendrą vaikų burnos sveikatos poveikio skalę, taip pat funkcinę gyvenimo gerovę, socialinę-emocinę gyvenimo gerovę, mokyklos aplinką, gydymo lūkesčius, bendrą burnos sveikatą.

5 lentelė. Vaikų, gimusių su skirtingais nesuaugimo tipais, surinktų balų palyginimas.

SD-standartine deviacija, $\bar{x}$ - vidurkis

\begin{tabular}{|c|c|c|c|}
\hline $\begin{array}{l}\text { COHIP klausi- } \\
\text { mynas }\end{array}$ & $\begin{array}{c}\text { Vienpusis lūpos ir gomu- } \\
\text { rio nesuaugimas }(n=34) \\
\text { Izoliuotas gomurio nesu- } \\
\text { augimas }(n=9) \\
\end{array}$ & $\overline{\mathbf{x}} \pm \mathbf{S D}$ & $\begin{array}{c}\text { Skirtumas } \\
\text { tarp tiria- } \\
\text { mųjų grupiụ }\end{array}$ \\
\hline $\begin{array}{l}\text { Bendras bur- } \\
\text { nos sveikatos } \\
\text { poveikio } \\
\text { skalès balas }\end{array}$ & $\begin{array}{l}\text { Vienpusis lūpos, alveolinès } \\
\text { ataugos ir gomurio nesuau- } \\
\text { gimas } \\
\text { Izoliuotas gomurio nesu- } \\
\text { augimas }\end{array}$ & $\begin{array}{c}106,54 \pm \\
12,55 \\
\\
114,22 \pm \\
15,17 \\
\end{array}$ & 7,68 \\
\hline $\begin{array}{l}\text { Su burnos } \\
\text { sveikata susi- } \\
\text { jusi gerove }\end{array}$ & $\begin{array}{l}\text { Vienpusis lūpos, alveolinès } \\
\text { ataugos ir gomurio nesuau- } \\
\text { gimas } \\
\text { Izoliuotas gomurio nesu- } \\
\text { augimas }\end{array}$ & $\begin{array}{l}25,57 \pm 5,15 \\
28,00 \pm 6,38\end{array}$ & 2,43 \\
\hline $\begin{array}{l}\text { Funkcinè } \\
\text { gyvenimo } \\
\text { gerové }\end{array}$ & $\begin{array}{l}\text { Vienpusis lūpos, alveolinès } \\
\text { ataugos ir gomurio nesuau- } \\
\text { gimas } \\
\text { Izoliuotas gomurio nesu- } \\
\text { augimas }\end{array}$ & $\begin{array}{l}17,39 \pm 3,53 \\
19,44 \pm 2,96\end{array}$ & 2,05 \\
\hline $\begin{array}{l}\text { Socialinė emo- } \\
\text { cinè gyvenimo } \\
\text { gerovė }\end{array}$ & $\begin{array}{l}\text { Vienpusis lūpos, alveolinès } \\
\text { ataugos ir gomurio nesuau- } \\
\text { gimas } \\
\text { Izoliuotas gomurio nesu- } \\
\text { augimas }\end{array}$ & $\begin{array}{l}25,21 \pm 4,73 \\
28,33 \pm 4,12\end{array}$ & 3,12 \\
\hline $\begin{array}{l}\text { Mokyklos } \\
\text { aplinka }\end{array}$ & $\begin{array}{l}\text { Vienpusis lūpos, alveolinès } \\
\text { ataugos ir gomurio nesuau- } \\
\text { gimas } \\
\text { Izoliuotas gomurio nesu- } \\
\text { augimas }\end{array}$ & $\begin{array}{l}14,50 \pm 1,53 \\
15,11 \pm 1,36\end{array}$ & 0,61 \\
\hline $\begin{array}{l}\text { Savęs suvo- } \\
\text { kimas }\end{array}$ & $\begin{array}{l}\text { Vienpusis lūpos, alveolinès } \\
\text { ataugos ir gomurio nesuau- } \\
\text { gimas } \\
\text { Izoliuotas gomurio nesu- } \\
\text { augimas }\end{array}$ & $\begin{array}{l}17,14 \pm 2,93 \\
19,56 \pm 4,57\end{array}$ & 2,42 \\
\hline $\begin{array}{l}\text { Gydymo } \\
\text { lūkesčiai }\end{array}$ & $\begin{array}{l}\text { Vienpusis lūpos, alveolinès } \\
\text { ataugos ir gomurio nesuau- } \\
\text { gimas } \\
\text { Izoliuotas gomurio nesu- } \\
\text { augimas }\end{array}$ & $\begin{array}{l}6,04 \pm 1,45 \\
6,44 \pm 1,51\end{array}$ & 0,4 \\
\hline $\begin{array}{l}\text { Bendra sveika- } \\
\text { tos būklè }\end{array}$ & $\begin{array}{l}\text { Vienpusis lūpos, alveolinès } \\
\text { ataugos ir gomurio nesuau- } \\
\text { gimas } \\
\text { Izoliuotas gomurio nesu- } \\
\text { augimas }\end{array}$ & $\begin{array}{l}2,79 \pm 0,83 \\
3,00 \pm 0,87\end{array}$ & 0,21 \\
\hline $\begin{array}{l}\text { Bendra burnos } \\
\text { sveikatos } \\
\text { būklè }\end{array}$ & $\begin{array}{l}\text { Vienpusis lūpos, alveolinès } \\
\text { ataugos ir gomurio nesuau- } \\
\text { gimas } \\
\text { Izoliuotas gomurio nesu- } \\
\text { augimas }\end{array}$ & $\begin{array}{l}2,39 \pm 0,83 \\
2,78 \pm 0,83\end{array}$ & 0,39 \\
\hline
\end{tabular}

Lyginant skirtingų lyčių pacientų atsakymus nei vienoje klausimų grupeje statistiškai reikšmingas skirtumas nenustatytas (4 lentelè).

Analizuojant skirtingus nesuaugimo tipus, pacientai, turintys abipusi lūpos, alveolinès ataugos ir gomurio $(n=5)$, izoliuotą lūpos $(n=1)$, centrinį nosies, lūpos ir alveolinès ataugos $(\mathrm{n}=1)$ bei lūpos ir alveolinès ataugos $(\mathrm{n}=1)$ nesuaugimą, i analizę neitraukti dèl nepakankamos imties. Palyginus vaikus su vienpusiu lūpos, alveolinès ataugos ir gomurio nesuaugimu bei vaikus su izoliuotu gomurio nesuaugimu statistiškai reikšmingas skirtumas tarp atsakymų nei vienoje klausimų grupeje nerastas (5 lentelè).

\section{Diskusija}

Šio tyrimo rezultatai parodo, kad burnos ir veido nesuaugimai turi reikšmingą ịtaką vaiko nuo burnos sveikatos priklausančiai gyvenimo kokybei (ang. Oral Health Related Quality of Life, OHRQoL). Gauti rezultatai patvirtina, kad vaiku, gimusių su burnos ir veido nesuaugimais, nuo burnos sveikatos priklausanti gyvenimo kokybė yra prastesnè. Tai ypač atsispindi vertinant jų funkcinę, socialinę-emocinę gyvenimo gerovę, savijautą, esant mokyklos aplinkoje. Taip pat jie prasčiau įvertino savo bendrą sveikatą bei bendrą burnos sveikatą. Tokie rezultatai buvo gauti ir kituose panašiuose tyrimuose $[8,9]$. Visgi Čilëje atlikto tyrimo rezultatai priešingi - nurodoma, kad nesuaugimą turinčių vaikų nuo burnos sveikatos priklausanti gyvenimo kokybė yra panaši i i sveikų vaikų [10]. Taip pat Broder ir Wilson-Genderson nurodo, kad vertinant gyvenimo kokybės rezultatus svarbu atsižvelgti ị tiriamojo asmens gydymo stadiją, nes randama tyrimų, kuriuose teigiama, jog vaikas su lūpos, alveolinès ataugos ir/ar gomurio nesuaugimu palaipsniui prisitaiko prie savo paties ịvaizdžio ir emocinès būklès bei pastaruosius vertina geriau dèl matomų gydymo rezultatų ar individualios adaptacijos [6]. Nei mūsų atliktame, nei anksčiau minètuose tyrimuose ị ši faktorių neatsižvelgiama, todèl tai gali būti laikoma minètų tyrimų trūkumu.

Lyginant pacientų, gimusių su veido nesuaugimais, bei tėvų atsakymus buvo pastebètas désningumas, jog tėvai žymiai prasčiau vertina atžalų gyvenimo kokybę nei patys pacientai. Mūsų atliktame tyrime buvo gautas statistiškai reikšmingai mažesnis bendras nuo burnos sveikatos priklausančios gyvenimo kokybès rezultatas. Tai ypač akivaizdu lyginant funkcinès gyvenimo gerovès, socialinės-emocinès gyvenimo gerovès bei mokyklos aplinkos kriterijus. Šie rezultatai sutampa su Maureen Wilson-Genderson ir bendraautorių tyrimu 
[11]. Jame buvo nustatytas išimtinai kaukolès-veido igimtus sutrikimus turinčių vaikų atsakymų nesutapimas su jų tėvais. Šie pacientai statistiškai patikimai geriau vertino savo būklę nei jų tèvai. Tai gali būti paaiškinama tuo, jog tèvai nuo mažens skaudžiai išgyvena savo atžalos problemas, o tai gali lemti padidintą jų rūpestị ir kartu iškreiptą mąstymą apie tikrają vaiko būklę. Tačiau randama ir prieštaringų rezultatų. Pavyzdžiui, tiriant 11-14 metų amžiaus vaikų ir jų motinų išsakomą nuo burnos sveikatos priklausančią gyvenimo kokybę, rasta, jog motinos ją vertino geriau [12]. Šias išvadas reiktų vertinti atsargiai, nes minèto tyrimo imtis nebuvo didelé, taip pat kokybès ịvertinimui naudota kita - ,Vaiko nuo burnos sveikatos priklausančios gyvenimo kokybès anketa“ (angl. Child Oral Health Quality of Life Questionnaire). Apibendrinant, mūsų tyrimo rezultatai šiuo klausimu gali būti vertinami dvejopai. Viena vertus, prastesnius tėvų atsakymus galèjo lemti jų ankstesni išgyvenimai. Tai iškelia dar vieną - psichologinès pagalbos tèvams problemą. Tačiau, kita vertus, 8-15 metų amžiaus vaikai galèjo tinkamai nesuprasti anketos arba ignoruoti savo problemas ir taip iškreipti rezultatus labiau teigiama linkme.

Lygindami skirtingas amžiaus grupes, nei vienoje klausimų grupeje statistiškai reikšmingo skirtumo neradome. Manome, kad lyčių ir nesuaugimų tipų pasiskirstymas abiejose grupèse ịtakos neturejjo, nes tarp skirtingų lyčių bei nesuaugimų tipų atsakymų statistiškai reikšmingas skirtumas nenustatytas. Tyrimui antrina ir kitos atliktos studijos, kuriose reikšmingas skirtumas tarp amžiaus grupių nerastas nei viename klausimų pogrupyje [13, 14].

Tyrimai rodo, jog nepilnamečių nuo burnos sveikatos priklausanti gyvenimo kokybė skiriasi priklausomai nuo lyties. Pavyzdžiui, 12 Europos šalių ir 21590 bendros populiacijos vaikų apimanti studija nurodè, jog didejjant mergaičių amžiui nuo 8 iki 18 metu jų subjektyviai vertinama nuo burnos sveikatos priklausanti gyvenimo kokybė mažèjo žymiai labiau nei berniukų [15]. Tačiau tarp ịgimtą veido nesuaugimą turinčių pacientų aiškių dessningumų rasti sunku, nes trūksta didelès imties tyrimų. Mūsų tyrime lyginant berniukų ir mergaičių atsakymus nei vienoje gyvenimo kokybès klausimų grupejje statistiškai reikšmingas skirtumas nenustatytas. Svarbu paminèti, jog mergaičių ir berniukų skaičius išsiskyrė atitinkamai 17 ir 28 tiriamujjų bei nebuvo atsižvelgta ị skirtingus nesuaugimų tipus tarp lyčių, o tai galèjo sąlygoti atsakymų paklaidas. Taip pat lyginome bendrai 8-15 amžiaus vaikus, nes dalinant tiriamuosius į 8-11 ir 12-15 metu grupes gaunama nereprezentatyvi imtis statistinei analizei. Jokio statistinio reikšmingumo tarp lyčių nebuvo rasta ir Olandijoje atliktame tyrime [16]. Taigi, remiantis mūsų atliktu tyrimu galima teigti, jog specialių gydymo modifikacijų atsižvelgiant ị paciento lytị nereikia. Tai sutampa su Olandijos tyrèjų duomenimis. Tačiau šios išvados nėra kategoriškos, nes labai svarbu yra lyginti vyrų bei moterų grupes, kurios suskirstytos pagal nesuaugimo tipą, kadangi šis kriterijus turi didelę įtaką fenotipiniams požymiams. Yra žinoma tik keletas tyrimų, kuriuose paauglių socialiniai-emociniai veiksniai vertinami atsižvelgiant ir į lytị, ir į nesuaugimo tipą. Pacientai skirstyti i turinčius matomą ir nematomą nesuaugimą. Nustatyta, kad nepasitenkinimas išvaizda ir didesnè rizika depresijos požymiams atsirasti būdinga mergaitèms $[17,18]$.

Mūsų atliktoje studijoje buvo lyginami tik vaikai, turintys vienpusi lūpos, alveolinès ataugos ir gomurio nesuaugimą su izoliuotu gomurio nesuaugimu. Tačiau imčiu pasiskirstymas buvo nevienodas (atitinkamai $n=28$ ir $n=9$ ). Lyginant šias tiriamuju grupes statistiškai patikimo skirtumo tarp bendro COHIP balo ar atskirų klausimų grupių nebuvo. Rastas tik nedidelis tyrimų skaičius, kur būtų lyginama nuo burnos sveikatos priklausanti gyvenimo kokybė vaikų su skirtingais burnos ir veido nesuaugimo tipais. Eslami ir kt. darbe tiriamieji buvo padalinti ị dvi grupes: vienpusiai lūpos ir gomurio nesuaugimai bei dvipusiai lūpos ir gomurio nesuaugimai. Lyginant bendrą COHIP bei atskirų pogrupių surinktą taškų skaičių, statistiškai reikšmingas skirtumas tarp grupių nerastas [14].

Bos A. ir Prahl C., lygindami gyvenimo kokybès rodiklius tarp vaikų su skirtingais nesuaugimo tipais, analizavo 4 vaikų grupes: vaikus su izoliuotais gomurio nesuaugimais, vaikus su lūpos arba lūpos ir alveolinès ataugos nesuaugimais, vaikus su vienpusiu lūpos ir gomurio bei vaikus su dvipusiu lūpos ir gomurio nesuaugimais. Nustatyta, kad tiriamieji su izoliuotu lūpos bei lūpos ir alveolinès ataugos nesuaugimais surinko didžiausią funkcinès gyvenimo gerovès pogrupio balą. Daugiau statistiškai reikšmingų skirtumų nerasta [16].

Vertinant vaikus, turinčius skirtingus burnos ir veido nesuaugimus, reikètų atkreipti dèmesį, kad kiekvienam jų taikomas skirtingas individualus gydymas, taip pat skirtingas tiriamujų amžius, todèl kiekvieno vaiko gydymo stadija skirtinga. Šie faktoriai gali iškreipti rezultatus esant sąlyginai nedidelei tiriamujų imčiai aptartuose tyrimuose.

Šis tyrimas neremiamas, nefinansuojamas ir autoriams interesų konflikto nebuvo.

\section{Išvados}

1. Pacientų, gimusių su lūpos, alveolinès ataugos ir/ar gomurio nesuaugimu nuo burnos sveikatos priklausanti gyvenimo kokybė yra prastesnè nei sveikų vaikų.

2. Tèvai savo vaikų, gimusių su nesuaugimu, gyvenimo kokybę vertina blogiau, nei patys vaikai. 
3. Amžiaus grupè, lytis bei nesuaugimo tipas neturi įtakos gyvenimo kokybei.

\section{Literatūra}

1. Mossey P a, Shaw WC, Munger RG, Murray JC, Murthy J, Little J. Global oral health inequalities: challenges in the prevention and management of orofacial clefts and potential solutions. Adv Dent Res 2011;23:247-58. https://doi.org/10.1177/0022034511402083

2. Mossey P a, Little J, Munger RG, Dixon MJ, Shaw WC. Cleft lip and palate. Lancet 2009;374:1773-85. https://doi.org/10.1016/S0140-6736(09)60695-4

3. Rumsey N, Stock NM. Living with a cleft: psychological challenges, support and intervention. In: Berkowitz S. (eds) Cleft Lip and Palate. Springer, Berlin, Heidelberg, 2013. https://doi.org/10.1007/978-3-642-30770-6_45

4. Ruscello D. Treatment of velopharyngeal closure for speech: Discussion and implications for management. The Journal of Speech and Language Pathology - Applied Behavior Analysis, 2007; 2(1): 55-75.

https://doi.org/10.1037/h0100212

5. Sischo L, Broder HL. Oral health-related quality of life: what, why, how, and future implications. J Dent Res 2011;90:126470. doi:10.1177/0022034511399918.

https://doi.org/10.1177/0022034511399918

6. Broder HL, Wilson-Genderson M. Reliability and convergent and discriminant validity of the child oral health impact profile (COHIP Child's version). Community Dent Oral Epidemiol 2007;35:20-31.

https://doi.org/10.1111/j.1600-0528.2007.0002.x

7. El Osta N, Pichot H, Soulier-Peigue D, Hennequin M, TubertJeannin S. Validation of the child oral health impact profile (COHIP) french questionnaire among 12 years-old children in New Caledonia. Health and Quality of Life Outcomes. 2015;13:176. doi:10.1186/s12955-015-0371-9.

https://doi.org/10.1186/s12955-015-0371-9

8. Ward J a, Vig KWL, Firestone AR, Mercado A, da Fonseca $\mathrm{M}$, Johnston W. Oral health-related quality of life in children with orofacial clefts. Cleft Palate Craniofac J 2013;50:174-81. doi:10.1597/11-055.

https://doi.org/10.1597/11-055

9. Antonarakis GS, Patel RN, Tompson B. Oral health-related quality of life in non-syndromic cleft lip and/or palate patients: a systematic review. Community Dent Health 2013;30:189-95.

10. Aravena PC, Gonzalez T, Oyarzún T, Coronado C. Oral healthrelated quality of life in children in Chile treated for cleft lip and palate: a case-control approach. Cleft Palate Craniofac J 2015;54:15-20. https://doi.org/10.1597/15-095

11. Wilson-Genderson M, Broder HL, Phillips C. Concordance between caregiver and child reports of children's oral he- alth-related quality of life. Community Dent Oral Epidemiol 2007;35:32-40.

https://doi.org/10.1111/j.1600-0528.2007.00403.x

12. Jokovic A, Locker D, Stephens M, Guyatt G. Agreement between mothers and children aged 11-14 years in rating child oral health-related quality of life. Community Dent Oral Epidemiol 2003;31:335-43.

https://doi.org/10.1034/j.1600-0528.2003.00012.x

13. Ward JA, Vig KWL, Firestone AR, Mercado A, da Fonseca $\mathrm{M}$, Johnston W. Oral health-related quality of life in children with orofacial clefts. Cleft Palate Craniofac J 2013;50:174-81. doi:10.1597/11-055.

https://doi.org/10.1597/11-055

14. Eslami N, Majidi MR, Aliakbarian M, Hasanzadeh N. Oral health-related quality of life in children with cleft lip and palate. J Craniofac Surg 2013;24:e340-3.

https://doi.org/10.1097/SCS.0b013e31828b743b

15. Michel G, Bisegger C, Fuhr DC, Abel T. Age and gender differences in health-related quality of life of children and adolescents in Europe: A multilevel analysis. Qual Life Res 2009;18:1147-57.

https://doi.org/10.1007/s11136-009-9538-3

16. Bos A, Prahl C. Oral health-related quality of life in Dutch children with cleft lip and/or palate. Angle Orthod 2011;81:865-71. https://doi.org/10.2319/070110-365.1

17. Feragen KB, Kvalem IL, Rumsey N, Borge AIH. Adolescents with and without a facial difference: The role of friendships and social acceptance in perceptions of appearance and emotional resilience. Body Image 2010;7:271-9.

https://doi.org/10.1016/j.bodyim.2010.05.002

18. Crerand CE, Sarwer DB, Kazak AE, Clarke A, Rumsey N. Body image and quality of life in adolescents with craniofacial conditions. Cleft Palate-Craniofacial J 2017;54:2-12.

https://doi.org/10.1597/15-167

\section{ORAL HEALTH-RELATED QUALITY OF LIFE IN CHILDREN WITH OROFACIAL CLEFTS}

L. Zaleckas, L. Linkevičienė, G. Aidukaitè, G. Bagušauskaitė

Key words: cleft lip, cleft palate, caregivers, quality of life, oral health, COHIP.

Summary

In Lithuania, approximately one of 700-800 infants born alive has a cleft lip, cleft alveolar process and/or cleft palate. It is a complex pathology that involves anatomical, physiological and psychological processes that changes the quality of life.

The aim of the work is to evaluate patients with cleft lip and/ or palate oral health related quality of life (OHRQoL) and to assess whether OHRQoL differs between children with different cleft types, between age groups and genders. Also, to identify the difference between responses of children with orofacial clefts and their caregivers.

Materials and methods. 45 patients with cleft lip and/or palate 


\section{6}

from Žalgiris Clinics of Vilnius University Hospital, as well as one of their caregivers and 45 controls completed a Lithuanian version of standardized questionnaire - Child Oral Health Impact Profile (COHIP) with the purpose to evaluate self reported OHRQoL. Children age was $8-15$ years.

Results. Children with orofacial clefts had statistically significant poorer quality of life $(\mathrm{p}<0,001)$. The average overall score of the COHIP was $108,80 \pm 13,26$ for the group of children with cleft and 125,78 $\pm 11,43$ for the control group. Mostly, this is seen then evaluating Functional Well-being, Social-emotional Wellbeing, School Environment, Global Health $(\mathrm{p}<0.001)$ and Global Oral Health $(p=0.05)$. There was no statistically significant difference between answers of different age groups, genders and different type of clefts. Also, there was found that caregivers assessing oral health related quality of life worse than their children, espe- cially Functional Well-being, Social-emotional Well-being, School Environment and Global Oral Health.

Conclusions. Presence of an orofacial cleft significantly decreases oral health related quality of life in children. Caregivers reported worse oral health related quality of life of their children than did the children themselves. Age, gender and cleft type have no impact on oral health related quality of life.

Correspondence to: aidukaitegr@gmail.com

Gauta 2018-02-27 